Portland State University

PDXScholar

\title{
The Suits That Counted: The Judicialization of Presidential Elections
}

\author{
Charles Anthony Smith \\ University of California - Irvine \\ Christopher Shortell \\ Portland State University
}

Follow this and additional works at: https://pdxscholar.library.pdx.edu/polisci_fac

Part of the American Politics Commons, and the United States History Commons

Let us know how access to this document benefits you.

\section{Citation Details}

Smith, C., \& Shortell, C. (2007). The Suits That Counted: The Judicialization of Presidential Elections. Election Law Journal, 6(3), 251-265. doi:10.1089/elj.2007.6303

This Article is brought to you for free and open access. It has been accepted for inclusion in Political Science Faculty Publications and Presentations by an authorized administrator of PDXScholar. Please contact us if we can make this document more accessible: pdxscholar@pdx.edu. 


\title{
The Suits That Counted: The Judicialization of Presidential Elections
}

\author{
CHARLES ANTHONY SMITH and CHRISTOPHER SHORTELL
}

\begin{abstract}
The litigation resolving the 2000 election received extensive attention, but there was also an increase in pre-election litigation in 2000, suggesting an increased reliance on courts even prior to Bush v. Gore. Did this trend of judicialization of presidential elections in the United States accelerate in 2004? To answer this question, we collect data on pre-election litigation from 1992, 1996, 2000, and 2004. Our findings show that the rate of prospective litigation increased dramatically in the 2004 election, even accounting for state and federal electoral reform from 2001-2004. Beyond the increase in raw numbers, we find that the litigation was distributed strategically based on predicted closeness of the state and the number of electoral votes at stake. We conclude with a discussion of the implications of this development.
\end{abstract}

\section{INTRODUCTION}

After the 2000 presidential election was resolved in George W. Bush's favor, much of the scholarly attention focused on the legal dimensions of Bush v. Gore and the Court's institutional or public standing (Chemerinsky 2001; Gibson, Caldeira, and Spence 2003). In the ensuing years, numerous articles and books addressed the decision's implications for the doctrine of equal protection, public support of the Court, and the political preferences of the jus-

Charles Smith is Assistant Professor of Political Science at University of California, Irvine. Christopher Shortell is Assistant Professor of Political Science at California State University, Northridge. An earlier version of this article was presented at the 2005 American Political Science Association Annual Meeting. The authors would like to thank Ben Bishin, Amy Bridges, Jeff Drope, Alec Ewald, Vikram Jagadesh, Casey Klofstad, the anonymous reviewers, and the editors of Election Law Journal. The authors gratefully acknowledge funding support from the College of Social and Behavioral Sciences, California State University, Northridge. tices (Banks, Cohen, and Green 2005; Clayton 2002; Hasen 2001, 2004; Levinson 2002; Posner 2001; Sunstein and Epstein 2001). Certainly, the Court has received substantial criticism for its involvement in the 2000 election (Gillman 2001; Balkin 2001; Garrett in Sunstein and Epstein 2001; Mebane 2004). Recently, the scholarly focus has turned to what effect the 2000 presidential election may have on litigation and the role of the judiciary in future presidential elections (Foley forthcoming 2007; Hasen 2005; Lowenstein forthcoming 2007; Tokaji 2005).

An expansion of the role of litigation in presidential elections would be consistent with the broader trend of increased involvement by the judiciary in spheres formerly reserved to legislatures and executives. Judicialization is the term most commonly used to describe this shift. This phenomenon has received substantial notice in the academic literature, especially in the study of comparative politics (Ferejohn 2002; Hirschl 2004; Pildes 2004; Shapiro and Stone Sweet 2002; Tate and Vallinder 1995). Did the legal decisions in the 2000 election acceler- 
ate the trend of judicialization of elections in the United States? In his 2002 article, Ran Hirschl argued that Bush v. Gore is best understood in the context of judicialization because it increases judicial involvement in the areas of "political transformation, regime change, and electoral disputes" (Hirschl 2002, 192). Is this change sustained over time or was the 2000 election an anomaly? What is the effect of the 2000 presidential election on future presidential contests? Did the increase in litigation begin after the 2000 election or was the trend developing prior to that? Is this an example of the increasing use of "electoral law as political strategy" (Hasen 2005, 957)?

Our findings below suggest that the effect is lasting and that political actors use litigation both more frequently and more strategically than in the past. Comparative data from the 1992, 1996, 2000, and 2004 elections allow us to consider whether parties, candidates, and interest groups have increased their likelihood of litigating to gain electoral advantage and solve potential electoral disputes. ${ }^{1}$ We attempt to answer this question by comparing the pre-election litigation from the four most recent presidential elections for all fifty states and the District of Columbia. By considering both the quantitative and qualitative shifts in litigation strategy, we demonstrate that pre-election litigation has become an increasingly central part of the normal presidential election strategy, at least when a close election is anticipated.

An increase in lawsuits in 2004 was not unexpected, but were the suits widespread and random or were they narrowly focused in key competitive areas? We develop a logic of litigation that suggests the parties will litigate in predictable ways driven by electoral strategy. As a result, litigation is likely to play a far more prominent role in areas where the election is prospectively close. Close elections alone are not sufficient, however. Given the expense of litigation, we would expect to find most suits centered in close races with rich electoral pay-offs. In other words, Ohio is likely to see far more litigation than either Illinois (low competitiveness) or New Hampshire (low electoral votes). While Hasen $(2005,946)$ points out this incentive structure with regard to post-election litigation, the logic holds true for pre-election strategies.
Our analysis is not intended to suggest that litigation was unimportant to parties historically. Numerous examples of party directed litigation abound, not only in areas such as redistricting, but also in arenas of more extensive litigation by interest groups such as challenges to practices like the white primaries. Nor do we intend to suggest that parties were not previously interested in influencing the "rules of the game" for elections. Nonetheless, we argue that the electoral landscape has changed in significant ways since 2000 . In particular, there is an increased emphasis on litigation relating to the presidential election. Most of the prior litigation related to Congressional, state, and local issues. In the 1992 and 1996 presidential elections, pre-election litigation was almost non-existent. In 2000, both parties faced a remarkably close election and there was a consequent increase in the number of pre-election lawsuits filed. 2004 saw a significant acceleration of this trend and a dramatic increase in the number of suits filed.

The difference in the political landscape and logic after the 2000 election is that the political players now perceive the judiciary as a venue of first rather than last recourse. The strategic political lesson from the 2000 election litigation is that preventive (pre-election) litigation is a strategy far more likely to be successful than restorative (post-election) litigation. That is, courts are seen as one of the primary arenas for challenging the rules of the game before the election. At a minimum, the costs of failing to anticipate problems before election day are substantial enough that parties are unlikely to risk a more passive strategy. ${ }^{2}$ While the outcome of the 2000 election did not initiate this trend, as evidenced by the increase in filings prior to that election, it does appear to have so-

\footnotetext{
${ }^{1}$ Our study does not address the further question of plaintiff success through litigation. The most we can conclude is that the conditions necessary for judicialization are present. However, it is reasonable to assume that rational actors would not continue to file suits if there were no benefits to be gained from them.

2 Obviously, not all legal challenges can be brought prospectively. Concerns about standing caused one judge on the Sixth Circuit to vote to deny an injunction in Summit County Democratic Central \& Executive Committee $v$. Blackwell, 388 F.3d 547 (6th Cir. 2004).
} 
lidified the developing notion among political actors that the courts are now a critical component of a successful electoral strategy.

In light of the events following the 2000 presidential election, there is significant reason to believe that courts will be more involved in future electoral disputes. The now-completed 2004 presidential election offers the first opportunity to test whether the trend seen in 2000 is continuing or was an anomaly. We expect to find a.change in the raw number of suits filed, a shift in the substance of the suits from local concerns to those that might alter the presidential election outcome, and an increased involvement of national political actors in the initiation of litigation. We also expect to find that the lawsuits in 2004 will be used in ways that are most likely to advance electoral victory, particularly in battleground states. An absence of any meaningful difference in these dimensions of litigation from 2000 to 2004 would suggest that the increase of litigation before the 2000 election is not indicative of a developing pattern. As we will discuss, our findings confirm that litigation as a campaign and electoral strategy now holds a far more prominent place for political actors. These findings suggest that judicialization of presidential elections had begun before the 2000 Florida controversy and that the Florida controversy accelerated the pace.

\section{METHODOLOGY}

To address the question of whether there was a change in the election strategy between the 2000 and 2004 presidential elections, we collected data on election-related cases filed in each state and the District of Columbia in both years. To test whether any change from 2000 to 2004 was a new development or a continuation of an earlier trend, we also collected data on electionrelated cases filed in 1996 and 1992. We used the calendar year through election-day as our time parameter. ${ }^{3}$ In order to generate a comprehensive set of relevant cases, we relied upon a combination of Lexis-Nexis searches and a review of daily newspaper accounts. ${ }^{4}$

Of the cases collected, we included only those filed before the close of election-day. ${ }^{5}$ The filing of suits after an election is dependent almost entirely on whether the suits have any likelihood of changing the outcome of the race. Where the election-day results are close or within the "margin of litigation," as in 2000, there will be more post-election lawsuits (Hasen 2005, 938). Where the election-day results are not as close, as in 2004, post-election lawsuits are unlikely. As a result, any differences in the number of lawsuits filed after an election tell us little about whether relevant parties are more inclined to use the courts as part of their election strategy.

In addition, the Court granted certiorari in Bush v. Palm Beach County Canvassing Board to address concerns about trying to change the rules after the election (531 U.S. 70 [2000]). This signals to potential litigants that it is better to file suits before the election rather than after, and we would expect the relevant parties to respond to this doctrinal message. Additionally, a post-election strategy puts the litigants in a position to be framed as sore losers by their opponents. ${ }^{6}$ Finally, study of cases filed prior to elections provides a more complete picture of the strategic calculations of political parties,

${ }^{3}$ It is possible that some cases were filed the year before, but it is unlikely that they were a significant number. Any action filed after the election would be geared towards restorative justice rather than electoral strategy.

${ }^{4}$ The full listing of cases is available at <http://www. csun.edu/ $\sim$ cshortell/electioncasesmatrix.xls $>$. LexisNexis provides access to all opinions of state appellate and supreme courts as well as written opinions from all federal courts. Search terms included "election," "candidates," and "voting." Data collected from Lexis-Nexis were supplemented by news accounts of the filing of cases. Specifically, we collected the case name, the state the case was filed in, the jurisdiction (state or federal), and the claim being made by the plaintiff. Where possible, we also included the outcome of the case, but our data on that are not comprehensive so we could not use it to draw any conclusions. Any specific case that may have been overlooked would be unlikely to alter our findings in any significant way. For further verification of our 2004 totals, we compared our dataset to one published by electionline.org, the only other reasonably complete list of cases, and we had identical or more comprehesive data for all states. (litigation update, Feb 14, 2005, electionline.org). 5 We also excluded cases during the relevant years that addressed previous elections or elections that were not held on the same days as the primary or general elections. ${ }^{6}$ Consider the Republican campaign sign parodies of "Sore/Loserman" in the type, color and design of the "Gore/Lieberman" signs. 
candidates, and interest groups that can be attained from post-election cases. These actors would not be expected to commit scarce resources before an election without a reasonable belief that the commitment of the resources would result in some pay-off. For all these reasons, we consider prospective lawsuits, those filed before an election, to be a reasonable measure of differences in strategy in presidential elections between 1992 and 2004.

States that are expected to be close should attract more litigation. States that are expected to be close and also are rich in electoral value should attract the most litigation. Not only are political parties more focused on these states, but interest groups are also more actively mobilized and likely to take action. Conversely, states that are not close should have little litigation and states that are not close and have little electoral value should have virtually no litigation. While states that are both closely contested and rich in electoral votes have always drawn the most attention from campaigns, pre-election litigation previously has not been an important element of this attention. If, contrary to our expectations, election litigation were not viewed strategically before or after 2000 , we would expect to find a random distribution of cases across all states.

We collected summaries of the facts for each case, including the legal basis of the claims as pleaded by the parties. We then sorted the cases into three categories based on subject area. The first category is Ballot Access. Ballot access includes any case addressing the inclusion of a candidate, party, or election oriented initiative on a ballot. For example, there were a number of challenges alleging that parties or candidates either failed to comply with qualifying rules or were being improperly denied a place on a ballot. The second category is Voter Access and Registration. This category includes any case dealing with the act of voting, including cases about absentee ballots, pre-election day voter harassment, felony purge lists, or registration requirements. Our third and final category is Ballot Counting. This group of cases includes challenges to canvassing board standards, ballot design, voting machine technology, and recount procedures. ${ }^{7}$
Table 1. Total Election Cases FILed DuRING 1992 CyCle

\begin{tabular}{lccc}
\hline & $\begin{array}{c}\text { State } \\
\text { Cts }\end{array}$ & $\begin{array}{c}\text { Federal } \\
\text { Cts }\end{array}$ & Total \\
\hline Ballot Access & 1 & 0 & 1 \\
Voter Acc/Reg & 0 & 0 & 0 \\
Ballot Counting & 0 & 0 & 0 \\
Total & 0 & 0 & 1 \\
\hline
\end{tabular}

These categories provided a mechanism for sorting the cases for the purpose of detecting changes in the substantive nature of the litigation from election to election. We also distinguished between federal and state jurisdiction in order to assess whether litigants preferred one forum over the other. These procedures generated comparable data sets from the 1992, 1996, 2000, and 2004 election cycles. Additionally, we sought to account for the wave of legislative electoral reform that took place in the wake of the 2000 elections. All of the 2004 cases arising from a dispute over new electoral rules are separately identified and addressed.

We will first consider the quantitative data from all the states and the District of Columbia, discussing changes over time as well as the substance of the litigation. We then consider the data from the "battleground" states. After we examine the data, we consider its implications, draw some general conclusions, and make some suggestions for additional research.

\section{CASES PRIOR TO THE 1992, 1996, AND 2000 PRESIDENTIAL ELECTIONS}

By collecting data from the 1992, 1996, and 2000 election cycles, we established a baseline for comparison with events in 2004. We determined the number of suits filed, the jurisdic-

\footnotetext{
${ }^{7}$ Our classifications of the cases are, in practice, mutually exclusive. This is a reflection of the subject matter of the cases, rather than forcing cases into only one category. Ballot access suits, for example, dealt exclusively with ballot access issues and not with ballot counting. This has the added benefit of allowing us to avoid double-counting any cases.
} 
tion of those suits, as well as the substantive issues addressed by each case. By reviewing this information, we are able to get an overview of litigation activity prior to these elections. Tables 1,2, and 3 show the numbers and types of action in each of the three election cycles filed in all fifty states and the District of Columbia.

In both 1992 and 1996, there was only one pre-election case filed that was related to the presidential election. In 1992, the Wisconsin State Supreme Court heard a ballot access case brought by the ACLU in an effort to secure a place for ex-Klansman David Duke on the Republican presidential preference (primary) ballot. And in 1996, a federal court dismissed an action to force New Hampshire to comply fully with the Motor Voter law. Hasen finds 108 election related lawsuits nationwide in 1996, but all 107 other cases deal with state or Congressional races $(2005,958) .{ }^{8}$

These data suggest that while election litigation was going on, the focus was not on the presidential race. This is particularly striking for 1992, given the competitiveness of the election and the inclusion of a prominent third party candidate, Ross Perot. Despite these factors, there was no litigation filed in an attempt to control ballot access for Perot or to alter voter access or registration. Lewis-Beck and Squire suggest that party efforts may have been directed toward legislative efforts to heighten ballot access requirements such as signaturegathering to keep third party candidates off the ballot (1995; see also Ansolabehere and Gerber 1996). The absence of Perot-related litigation offers some support for this view and suggests that the two major parties and their supporters did not consider the courts to be a viable strategic avenue.

The election of 2000 presents a marked contrast. State courts entertained a total of 17 cases

Table 2. Total Election Cases FILEd DuRING 1996 CyCle

\begin{tabular}{lccc}
\hline & $\begin{array}{c}\text { State } \\
\text { Cts }\end{array}$ & $\begin{array}{c}\text { Federal } \\
\text { Cts }\end{array}$ & Total \\
\hline Ballot Access & 0 & 0 & 0 \\
Voter Acc/Reg & 0 & 1 & 1 \\
Ballot Counting & 0 & 0 & 0 \\
Total & 0 & 1 & 1 \\
\hline
\end{tabular}

Table 3. Total Election Cases FILED DURING 2000 CYCLE

\begin{tabular}{lccc}
\hline & $\begin{array}{c}\text { State } \\
\text { Cts }\end{array}$ & $\begin{array}{c}\text { Federal } \\
\text { Cts }\end{array}$ & Total \\
\hline Ballot Access & 9 & 15 & 24 \\
Voter Acc/Reg & 6 & 14 & 20 \\
Ballot Counting & 2 & 2 & 4 \\
Total & 17 & 31 & 48 \\
\hline
\end{tabular}

while 31 federal suits were filed for a total of 48 cases across the country. Several states had multiple suits in 2000. Pennsylvania had the most with seven cases. New Mexico had the second most with five. Michigan, North Carolina, and Washington each had four cases. Florida, Illinois, and New York each had three cases. California, Connecticut, Ohio, and Oregon each had two cases. Seven states had one case and thirty-one states and the District of Columbia had no pre-election litigation at all in 2000. Clearly the anticipated closeness of the election played a major, although not exclusive, role in an increased reliance on courts to mediate electoral disputes, even prior to election day. The pattern is one of increased judicialization of elections over time, though the increase in presidential election litigation from 1992 to 2000 is sudden rather than gradual.

The notable jump in ballot access litigation from 1992 to 2000 is perhaps attributable to retrospective consideration of the 1992 election. Given the impact of Perot on the 1992 election, the parties may have worked harder administratively to exclude third party candidates such as Nader and Buchanan from the ballot, necessitating the move to the courts by their supporters.

Most of the ballot access cases in 2000 involved third parties such as the Green Party or the Libertarian Party and their candidates. Connecticut, for example, saw actions to secure a spot on the ballot by both Pat Buchanan and Lyndon LaRouche. In Florida, Buchanan and Hagelin litigated over who could claim ballot access as the Reform Party candidate. Buchanan sued for inclusion on the Michigan

\footnotetext{
${ }^{8}$ Hasen's database of cases is available at <http://www.
} electionlawblog.org/archives/washleeappendix.xls $>$. 
SMITH AND SHORTELL

ballot. Ralph Nader or the Green Party filed similar suits in Illinois, New York, North Carolina, Ohio, and West Virginia.

Most of the voter access and registration cases involved issues such as the right of felons to vote or the ease with which registration could be accomplished. Litigation in Florida sought to restore felons' rights to vote, although all parties acknowledged the matter would not be resolved before the 2000 election. In Georgia, the United Nuwabian Nation of Moors sought to replace members of their group that had been purged from the voting rolls for a variety of different reasons. A case in Illinois sought to permit late registration for a group of teenagers whose original registrations were ruled invalid because of technical deficiencies. A Maryland case sought to allow college students to register to vote where they were enrolled rather than at their home addresses.

The four ballot counting cases were limited to questions about absentee ballots or the handling of ballots. For instance, the Republican Party sued in New Mexico to stop a mass mailing of absentee ballots and in Oregon where it claimed a county failed to secure ballots after a primary. Our findings strongly suggest that between 1992 and 2000, a change began to take place in the role of election litigation. ${ }^{9}$ The reasons for this development are not entirely clear, but are likely related to the broader trends of judicial involvement in democratic politics identified by scholars such as Hirschl and Pildes (Hirschl 2002; Hirschl 2004; Pildes 2004). This change, however, was still nascent and did not involve much participation from the most prominent and institutionalized political actors such as the two major parties and their presidential candidates until after the election. The expanded use of the courts in these three areas before the election as well as the post-election litigation in 2000 paved the way for the more aggressive participation of these political actors and a litigation explosion in 2004.

\section{CASES PRIOR TO THE 2004 PRESIDENTIAL ELECTION}

We used the same method of collection and categorization for the presidential election of
Table 4. Total Election Cases Filed During 2004 CrCle

\begin{tabular}{lccr}
\hline & $\begin{array}{c}\text { State } \\
\text { Cts }\end{array}$ & $\begin{array}{c}\text { Federal } \\
\text { Cts }\end{array}$ & Total \\
\hline Ballot Access & 27 & 14 & 41 \\
Voter Acc/Reg & 24 & 27 & 51 \\
Ballot Counting & 14 & 8 & 22 \\
Total & 65 & 49 & 114 \\
\hline
\end{tabular}

2004 as for the previous elections. Litigation in 2004 leaped beyond the already increased level found in 2000. Table 4 presents the numbers and types of actions filed prior to the 2004 election in all fifty states and the District of Columbia.

In 2004, state courts entertained a total of 65 cases while 49 federal suits were filed for a total of 114 cases across the country. This is a 137.5 percent increase in litigation over 2000. While the litigants somewhat favored state courts over federal courts, both state and federal venues were active locales for litigation. Parties, candidates, and interest groups availed themselves of both avenues of judicial involvement. Indeed, given the complex interactions of state and federal election laws, it is not a surprise that litigants used both venues. While our data do not allow us to draw firm conclusions about the presence of forum shopping, it is likely that litigants chose venues based primarily upon where they believed they could most likely prevail. These considerations could include the specific protections afforded by state or federal laws, the nature of the legal claims being pursued, or the desire to reach politically sympathetic judges. Regardless, it is consistent with the mixed federal/state nature of electoral laws in the United States to find litigation increase in both jurisdictions.

Ballot access litigation emerged as a specific party strategy in 2004 as the 41 ballot access cases were almost exclusively efforts to secure or deny a place on the ballot for Ralph Nader

\footnotetext{
${ }^{9}$ The absence of a competitive election in 1996 may make the change appear more sudden than it was. Had 1996 been a close election, we might have seen an increase in election litigation over 1992, although not necessarily to the degree seen in 2000 .
} 
TAble 5. NADER CASEs, 2000 vs. 2004

\begin{tabular}{lcc}
\hline & 2000 & 2004 \\
\hline Suits seeking inclusion of Nader & 5 & 17 \\
Suits seeking exclusion of Nader & 0 & 11 \\
\hline
\end{tabular}

whether through the Green Party or the Reform Party. In Arizona, for example, one suit sought to force Nader's inclusion on the ballot while one suit sought to force his exclusion from the ballot. In fact, with the exception of one case in Kansas that sought an order allowing only Republicans to vote in the Republican primary, one case in Washington seeking to put the Libertarian Party on the ballot, and one case in Utah seeking to put a different Green Party candidate (Cobb) on the ballot, all of the ballot access cases in 2004 involved Nader. The assumption was that Nader on the ballot would help Bush and hurt Kerry. The premise underlying this assumption is that some Nader voters would vote for Kerry as an alternative if Nader was unavailable. The Nader litigation increased in number and changed in nature from 2000 to 2004. Table 5 shows the growth in lawsuits relating to Nader from the 2000 cycle to the 2004 cycle.

The overt involvement of the Democrats and the Republicans in the Nader litigation in 2004 increased dramatically. In states such as Colorado and Wisconsin, the local Democratic Party was the named plaintiff in attempts to exclude Nader from the ballot. While either Nader or the Green Party would obviously be the plaintiff in litigation to include him on the ballot, the Republican Party provided support for Nader's signature gathering efforts (Stone 2004). That is, in 2000, the litigation had been driven by a sincere effort by Nader and the Green Party to secure a spot on the ballot with little participation in the litigation by outside parties. The litigation in 2004 was driven by the strategic efforts of the two major parties to secure or deprive Nader a spot on the ballot (Burden 2005; Burden 2006).

The question whether the presence or absence of Nader on ballots across the country actually changed the outcome of the presidential election speaks past the scope of this project. Indeed, given the general animus directed by
Democrats at Nader after the 2000 election as well as the diminished vote share by Nader in 2004, his presence or absence may have been inconsequential. ${ }^{10}$ Still, the concern about Nader on the ballot by both the Democrats and Republicans inexorably led to the use of preelection litigation to exclude or include him. ${ }^{11}$ Moreover, even if the Nader vote was inconsequential in the 2004 presidential vote distribution, given the closeness of the 2000 election and the vigorous attention paid to Nader by the parties in 2004, each party is likely to litigate aggressively when any third-party has some realistic chance of attracting enough votes to alter a race. If a candidate like Ross Perot ran today, that candidacy would face numerous litigation challenges to try and keep him off or put him on the ballot. That is, in future close elections with a competitive third party, the two major parties will litigate to keep ideologically close third parties off the ballot and third parties that are ideologically close to the opposition on the ballots.

Voter access and registration was also a heavily litigated area in 2004. A total of 51 cases sought primarily to expand or restrict the ability of citizens to vote. Many of the cases sought to repeal the ban on felons voting or simplify the process for the restoration of civil rights. For instance, Ohio and Florida saw litigation aimed at creating an automatic restoration of felons' rights to vote. Many suits sought to make the rules for registration or voting more or less restrictive. In Colorado, for example, an action was brought to eliminate the requirement that first time voters present photographic identification at the polls. An action in

\footnotetext{
${ }^{10}$ For example, according to the Florida Department of State, Division of Elections, in 2004, Nader received 32,971 votes or $.4 \%$ of the total presidential vote. In 2000 Nader received 97,488 votes or $1.6 \%$ of the total presidential vote. <http://election.dos.state.fl.us/elections/resultsarchive/Index.asp $>$.

${ }^{11}$ As suggested by the number of suits seeking the inclusion of Nader on the ballot, the efforts by supporters of Kerry's candidacy included many administrative attempts at exclusion in addition to efforts through the courts. A more aggressive legal strategy does not mean that remedies through election boards and secretaries of state are ignored. To the contrary, lawsuits provide a supplement in an environment where a candidate's supporters are seeking any advantage they can obtain.
} 
Nevada sought to extend the deadline for registration. Actions in Pennsylvania sought to prohibit felons from voting absentee and to allow additional time for overseas soldiers to vote. An action in Illinois sought to allow "stayat-home-moms" to vote by absentee ballot. Each side sought to shape the pool of voters in ways that would be most favorable to its preferred candidate. Generally speaking, supporters of Bush's candidacy tended to file suits over issues such as false registrations and the opportunity to challenge illegal voters, while supporters of Kerry's candidacy filed suits attempting to expand the number of possible voters through easier registration requirements and permitting felons to vote.

Given the litigation after the 2000 election regarding how votes would be counted or recounted, it is not surprising that ballot counting suits played an important role in 2004. This category of suits increased from four in 2000 to twenty-two in 2004 . The 22 ballot counting suits in 2004 addressed issues arising out of the switch to electronic voting, provisional ballots, and technically defective absentee and early voting ballots. For instance, cases in Ohio sought to prohibit the use of punch card voting, allow voters to cast provisional ballots in the event of registration errors, and allow access to paper ballots in precincts where long lines created lengthy waiting times to cast electronic votes. In Iowa and Florida, among others, suits were filed to force the inclusion of provisional ballots even if those ballots were cast in the wrong precincts. Litigation was filed in Maryland, Florida, and New Jersey seeking some sort of physical recount capacity where electronic voting systems left no paper-trail. The bulk of the ballot counting litigation was brought by plaintiffs favoring Kerry who sought to ensure that all ballots in Democratic strongholds would be counted. Provisional ballots, paper trails, and challenges to electronic voting were all thought to advance this cause.

A final point to make has to do with the significant increase in litigation brought in their own names by the two major political parties. Both parties increased their direct participation in litigation. Cases where either the Democratic or Republican party was the named plaintiff increased from five in 2000 to eighteen in
Table 6. Cases with Political Party as Plainttif

\begin{tabular}{lcr}
\hline & 2000 & 2004 \\
\hline Democratic Party as Plaintiff & 3 & 11 \\
Republican Party as Plaintiff & 2 & 7 \\
\hline
\end{tabular}

$2004 .{ }^{12}$ This measure understates the actual role of the political parties, since they also financially supported some lawsuits by individual voters and may have directed lawsuits by interest groups. Nonetheless, the change is stark. The political parties more directly asserted themselves in the realm of litigation than in past presidential elections.

\section{THE INFLUENCE OF ELECTORAL REFORM}

The increase to 114 cases related to the presidential election compared to 48 in 2000 and one each in 1992 and 1996 is undoubtedly substantial. However, the statutory landscape did not remain the same between 2000 and 2004. In fact, all 50 states engaged in fairly extensive electoral reform during the period and Congress passed the Help America Vote Act (HAVA) in 2002. Both Hasen (2005) and Tokaji (2005) suggest that electoral reform played a major role in the increase in litigation. Could these electoral reforms fully account for the increase in litigation between 2000 and 2004?

In order to answer this question, we identified each of the cases in 2004 that challenged or was based on a law or policy promulgated at the state or federal level between 2001 and 2004. For example, HAVA required that states provide the option of a provisional ballot to voters at the wrong precinct, so all provisional ballot cases can be considered electoral reform cases. Once we identified the cases, we removed them from our case totals as presented in Table 7.

There were 41 cases in 2004 that arose as a direct result of electoral reform. Removing

\footnotetext{
12 These cases include both national and state level polit-
} ical parties. 
Table 7. Total Non-Electoral Reform Cases Filed During 2004 CyCle

\begin{tabular}{|c|c|c|c|}
\hline & State courts & Federal courts & Total \\
\hline Ballot access & 26 & 13 & 39 \\
\hline Voter access + reg & 10 & 24 & 24 \\
\hline Ballot counting & 5 & 5 & 10 \\
\hline Total & 41 & 32 & 73 \\
\hline
\end{tabular}

them from our totals still leaves 73 cases, about a $50 \%$ increase over the 2000 totals. The majority of the remaining cases fell in the category of ballot access, particularly cases relating to the inclusion of Ralph Nader on the ballot. There were still substantial numbers of voter access and registration cases. The ballot counting cases constitute the smallest portion of the cases as before. Not surprisingly, these cases are also a smaller percentage of the total when the electoral reform cases are left out of account.

This method is obviously not perfect, since both the electoral reform and the decision to challenge a new electoral law are in part consequences of the 2000 election. The electoral reform movement certainly brought to light issues that were previously unchallenged and could have indirectly contributed to the increases seen in litigation in 2004. However, it is not clear that the election reform movement initiated lawsuits beyond those directly related to electoral reform. If anything, it is more likely that the information provided served as a signal to litigants about where to direct their litigation efforts rather than whether to initiate litigation at all. On the other side, it could be argued that our method is actually overstating the impact of electoral reform. In every election some of the litigation is based on new policies. In 2000, for example, 10 of the 48 cases were based on policies passed since the 1996 election. Nonetheless, even under the most conservative assumptions that all cases based on electoral reform should be excluded, the change between elections remains dramatic. We can conclude with a fair degree of confidence that the rise in litigation between 2000 and 2004 was not driven by electoral reform alone.

Another possible explanation is that litigation increased simply because the 2004 election was so close. The perceived closeness of the election is no doubt a major factor. However, the increase between 2000 and 2004 cannot be explained solely because 2004 was a close election. 2000 also featured a dramatically close election. If perceived closeness of election were the sole factor the electoral reform adjusted rates of litigation should have been similar between 2000 and 2004. Indeed, on that assumption there should have been more lawsuits in 1992. That there were almost no cases in 1992 and an almost $50 \%$ increase between the 2000 and 2004 elections suggests an expected close election is at most a necessary but not sufficient condition for a high level of litigation.

We argue that in addition to the closeness of the election and the increase in electoral reform, the relevant political actors learned an important lesson in 2000 and applied it in 2004. Preelection litigation can affect the outcome of the election and dedicating additional resources to legal battles is a necessary part of a successful electoral strategy. Courts, rather than potentially partisan electoral boards and secretaries of state, may offer a more effective means of preventing abuse of the electoral system by opponents or otherwise gaining an advantage. If political actors increasingly view litigation as a strategic tool, then, how does that affect the distribution of cases across states and subjects?

\section{A GRAPHIC COMPARISON OF 2000 AND 2004}

We find that the increase in litigation across the three subject areas was not idiosyncratic or random. Indeed, the new litigiousness of the presidential election was demonstrably strategic. An anticipated narrow vote margin in a state was not sufficient to cause a dramatic increase in litigation. A rich electoral college payoff was also insufficient to attract litigation resources before the election. However, a close race in an electorally rich state provided the necessary and sufficient conditions for the parties, candidates, and interest groups to commit to litigation.

We plotted the data in a three dimensional representation in order to show that states with a close vote spread and relatively rich electoral 
value saw the greatest increase in litigation. In Fig. 1 (2000) and Fig. 2 (2004), each state and the District of Columbia are represented by the circles. The Vote Spread, the percentile difference between the two major candidates, is plotted on the $Y$ axis (the axis on the far left of the diagram) while the electoral value, the number of Electoral Votes, is plotted on the $\mathrm{X}$ axis (the horizontal axis on the diagram). The number of Lawsuits is plotted on the $\mathrm{Z}$ axis. The $\mathrm{Z}$ axis illustrates through the loft (or height) the volume of lawsuits. For ease of interpretation, grayscale bands have been employed to illustrate the number of lawsuits. Each band represents one lawsuit. In representing the data, each figure uses the same dimensional scale, orientation, grayscale, contrast, and lighting. Selected states are labeled for ease of comparison.

The first observation to be gleaned from the charts is that litigation dramatically increased from the 2000 election to the 2004 election. Fur- ther, because we would expect those states with both close elections and rich electoral values (close/rich states) to have more litigation, we would expect those portions of the "blanket" of the three dimensional representation to be more peaked. A comparison of Figure 1 (2000) with Figure 2 (2004) shows an expansion of litigation not only across the board, but more dramatically in those close/rich states. Accordingly, we can conclude that since the close/rich states did indeed attract more litigation, the litigation was strategically driven.

A comparison of the charts shows that noncompetitive states such as California and Texas showed little movement in litigation rates despite rich electoral values. States with little electoral value, such as New Hampshire, also showed little change in litigant activity despite relatively close elections. As expected, states like Florida, Ohio, and Pennsylvania, all rich in electoral votes with competitive elections, drew dramatic increases in the volume of litigation

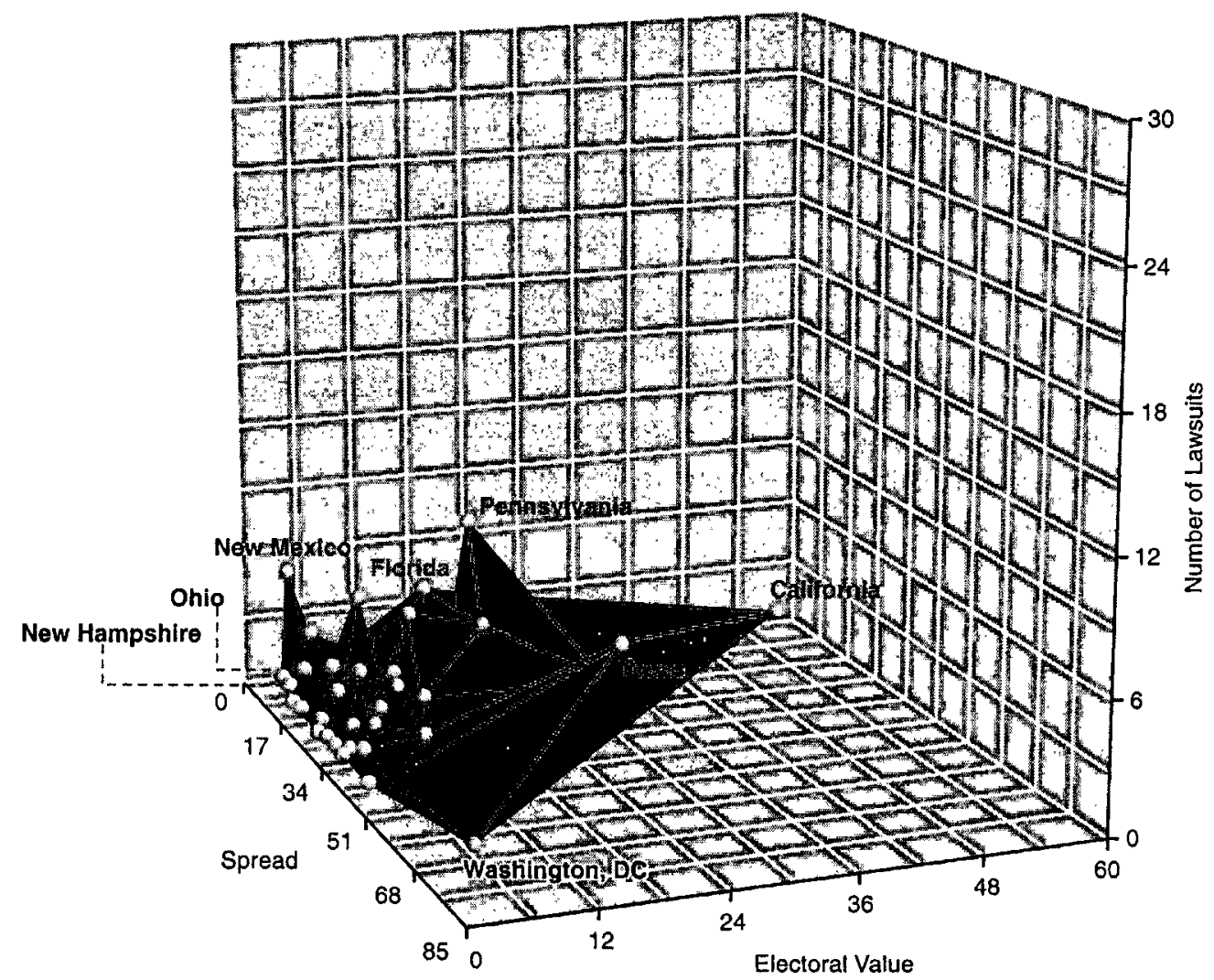

FIG. 1. (2000) Number of Lawsuit as a Function of Victory Margin and Electoral Value 2000 Election. 


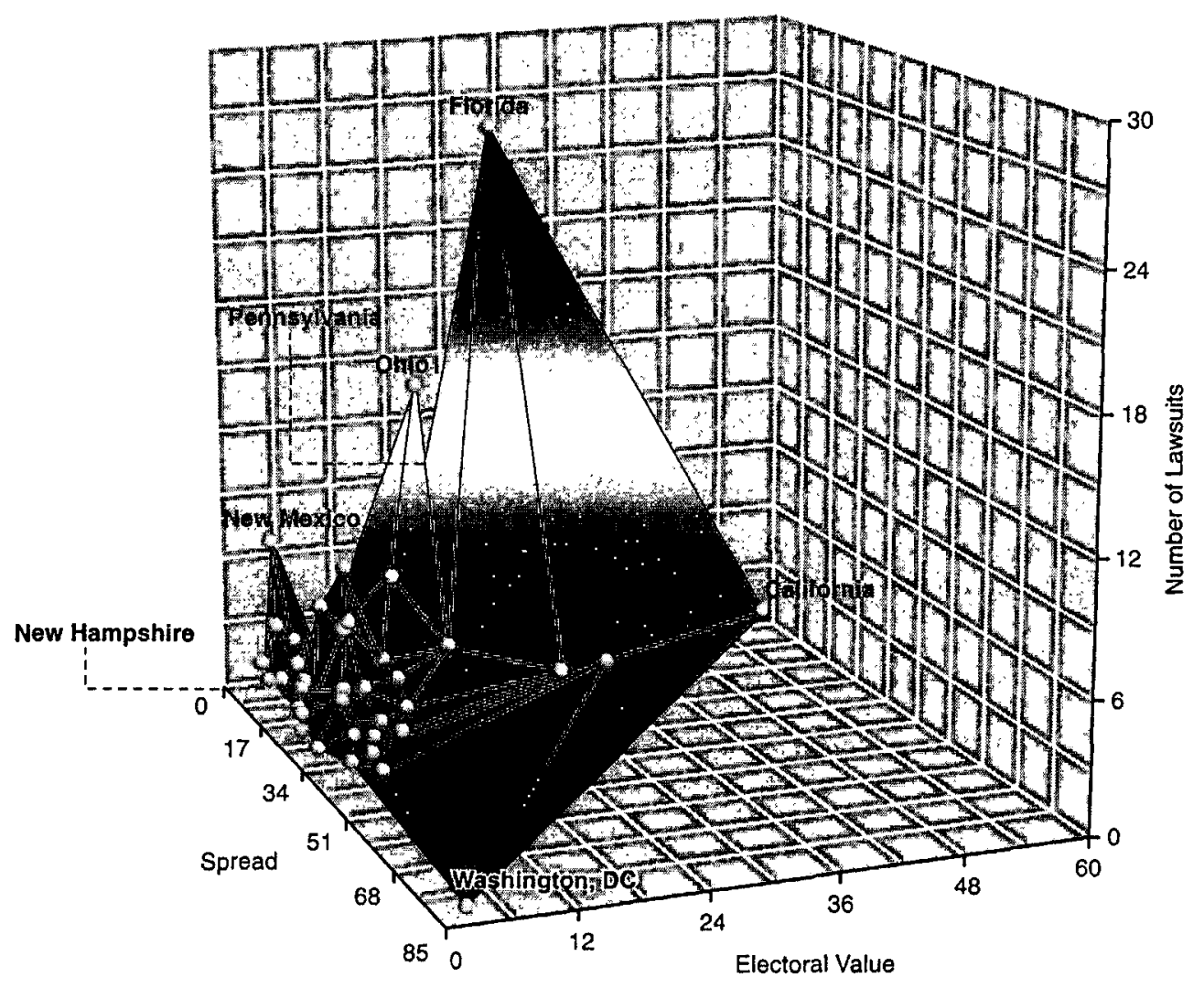

FIG. 2. (2004) Number of Lawsuit as a Function of Victory Margin and Electoral Value 2004 Election.

brought by the parties, candidates, and interest groups. While Florida and Ohio obviously drew the largest amount of litigation, as two of the most competitive states, those two states alone do not account for the increase. Removing all of the lawsuits from Florida and Ohio from our analysis still leaves 74 lawsuits filed in 2004, compared with 48 in 2000 . Consistent with our argument, the 74 remaining lawsuits are still arrayed strategically, with half of them being filed in the nine other battleground states.

To determine whether we were capturing something other than a random distribution of litigation across the states, we ran a negative binomial regression using vote spread (Spread) and electoral votes (Electoral Votes) as independent variables with the number of lawsuits as the dependent variable (Lawsuits). ${ }^{13}$ The vote spread is the percentile difference between the vote share of the two major parties. The electoral votes are the designated electoral votes each state may cast in the electoral college. As shown in Table 8, both Spread $(z=-4.40)$ and Electoral Votes $(z=4.15)$ are highly significant in the expected directions. That is, the closer the race and the greater the electoral value, the more likely litigation will happen. These directionally significant results are what we would expect if the litigation was strategicthat is, resources were utilized where the payoff could be maximized rather than in a random or idiosyncratic manner. The year (2004)

${ }^{13}$ We first ran a Poisson regression because like many incidents of counting events, the data follow a Poisson distribution. That is, the distribution is skewed, non-negative, and the variance likely increases as the mean increases. The Poisson model also assumes an equality of mean and variance. However, testing the Poisson regression, the large value of the Pearson Chi-sq (goodness of fit chi-sq was 277.34) indicated over-dispersion. Although the statistical and substantive results are virtually identical, we present the results of the negative binomial regression in the text in order to account for over-dispersion. 
Table 8. Negative Binomial Regression Analysis of LITTGATION, VOTE SPREAD AND ELECTORAL VOTES

\begin{tabular}{lrrrr}
\hline Lawsuits & Coef. & Std. Err. & $\mathrm{z}$ & $P>|\mathrm{z}|$ \\
\hline Spread & -0.0691631 & 0.016 & -4.40 & 0.000 \\
Electoral votes & 0.0615946 & 0.015 & 4.15 & 0.000 \\
Year dummy & 0.8596208 & 0.270 & 3.18 & 0.001 \\
Constant & -0.2007113 & 0.337 & -0.60 & 0.552 \\
\hline
\end{tabular}

Number of obs $=102$

LR chi2(3) $=50.35$

Prob $>$ chi2 $=0.000$

Log likelihood $=-143.57833$

Liklihood-ratio test of alpha $=0$ : chibar2(01) $=59.63$ Prob $>=$ chibar $2=0.000$

was used as a dummy variable and, because there were more suits, the intercept shifted significantly from 2000 to $2004(z=3.18)$.

Analysis of the data restricted to the battleground states also produced results consistent with our conclusions. We categorized a state as a battleground state if the final margin of victory was five points or less between the two major party candidates. While daily internal party polls would be the best source of determination for which states the parties considered to be battleground states, the final tally is a reasonable surrogate for the expectation of closeness. Moreover, little controversy exists as to which states were indeed battleground states for either 2000 or 2004 as there is a very close match between the states identified by the final margin and those identified in earlier polling (Cook 2004; Nagourney and Seeyle 2004). ${ }^{14}$ In Figure 3 (Battleground States), we show the magnitude of change in litigation rates for the eleven states we identified as battleground states. The bars represent the number of suits filed in each battleground state in 2004 in excess of the number of suits filed in 2000 . Predictably, the states that were both closest and richest in electoral votes had the greatest magnitude of change in litigation rates. Note that while Florida and Ohio had the greatest increases, the battleground states together accounted for 72 of the 114 total lawsuits filed in 2004 .

The aggregate data suggest that the location and substance of much litigation is driven by a desire for electoral advantage when the election is perceived as close. Far more than in previous elections, courts are seen as a strategic venue. Given the wide range and variety of avenues for litigation that can alter the rules for elections, it seems highly probable that in the future, major political parties and interest groups will develop litigation strategies well before close elections.

\section{IMPLICATIONS, CONCLUSIONS, AND ADDITIONAL RESEARCH}

From the results of our study, it seems clear that the role of litigation in 2000 was not an anomaly. Indeed, it was a precursor of an increased use of electoral law as political strategy in 2004. Even accounting for the intervening electoral reform legislation, the increase in the rate of litigation was substantial. Pre-election litigation has, therefore, assumed a far more prominent role in the election strategy of all political actors, at least when a close election is anticipated. While our findings must be situated in the larger context of increased judicialization over time, we argue that 2004 may have represented a critical tipping point in the process. Given the current competitive electoral landscape, there is no reason to anticipate a decline in litigation in the near future (Jacobson 2003).

We can also conclude that the parties will litigate in predictable strategic ways. Rather than merely filing suits wherever a potential problem may arise, they will dedicate litigation resources to states where cases are likely to have the greatest impact on the outcome of the election.

The events following the 2000 presidential election appear to have caused a number of changes in how the relevant political actors proceeded in 2004 . There is no question that political actors in 2000 were willing to engage in litigation at a significantly higher rate than in previous recent elections. Arguably this is a result of the anticipated closeness of the election, although it is also likely a consequence of the general trend of increased reliance on courts in

\footnotetext{
14 For example, both the Cook Political Report 2004 and the New York Tirnes 10/24/2004 listed the same battleground states as used here (Cook 2004; Nagourney and Seelye 2004).
} 


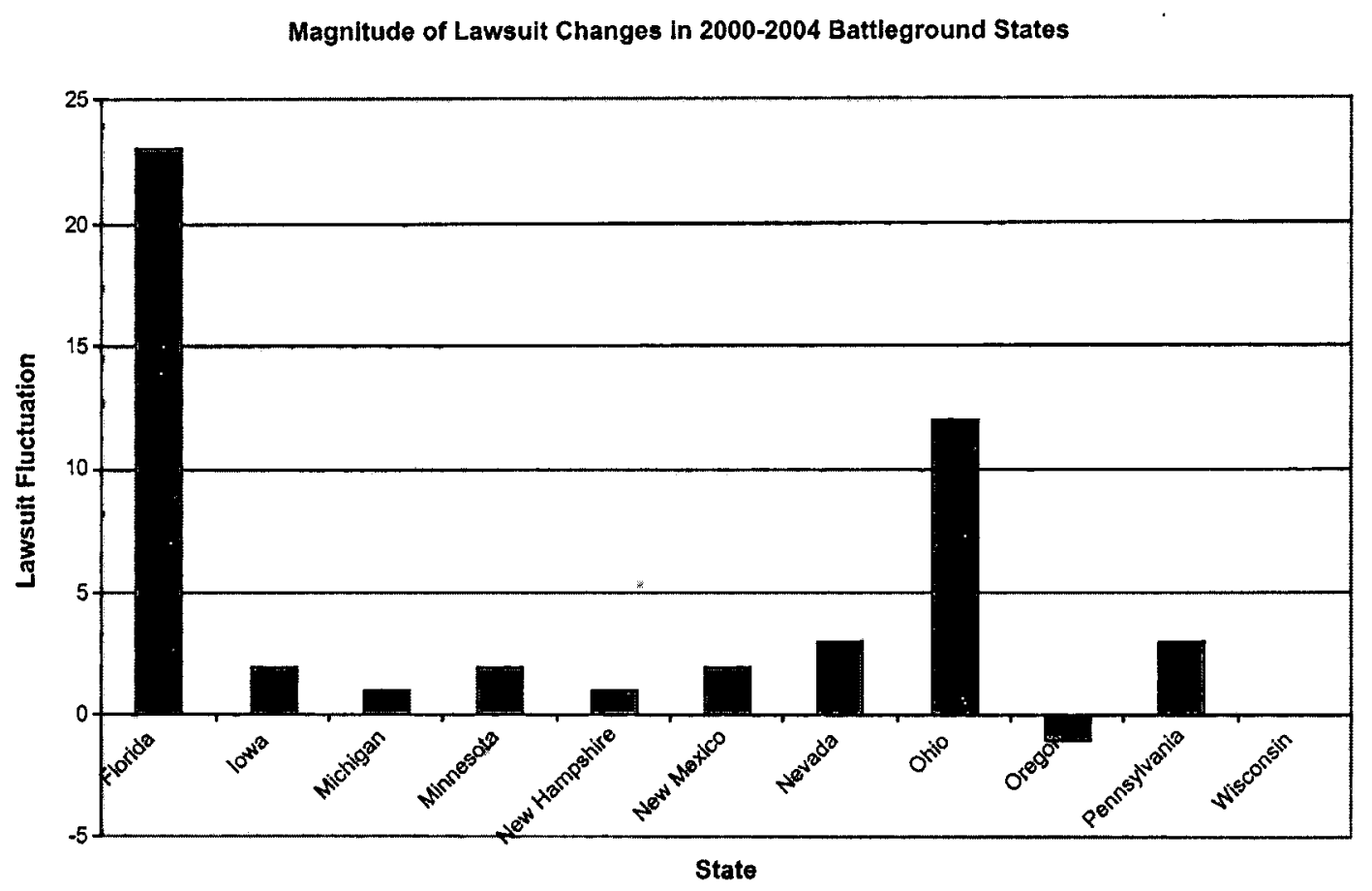

FIG. 3. Battleground States.

election controversies (Pildes 2004). In 2004, however, that activity multiplied dramatically in a similarly close election. This can be traced to several possible causes. Doctrinally, the Court's attempt to limit the scope of Bush $v$. Gore to "the present circumstances" was only partially successful as evidenced by the lawsuits in 2004 that explicitly relied on the Court's holding (Bush v. Gore 2000, 109). ${ }^{15}$

Beyond the doctrine, the courts signaled a willingness to hear election related disputes and, perhaps most importantly from the perspective of the judiciary, this intervention was accepted by the public, including those who disagreed with the outcome (Gibson, Caldeira, and Spence 2003). The perceived likelihood of the election results falling within the "margin of litigation" was also undoubtedly higher in 2004. Few political commentators predicted just how close the 2000 election would end up. Few wanted to make the same mistake in 2004. The possibility that presidential elections can be decided by relatively small changes in electoral rules or procedures is an acknowledged reality today. Most importantly, parties, candidates, and interest groups now recognize just how much can be lost by failing to engage in preventive litigation. The entire outcome of the 2000 presidential election could have rested on the court decisions in the following months. Our evidence shows that the stakes are clear to the relevant groups, especially the major political parties and their candidates. In contrast to 2000, the major political parties were more directly involved and this involvement likely legitimized further involvement by other litigants.

One question remains to be answered. How might these changes affect future presidential elections? The most obvious implication from this research is that parties, interest groups, and candidates now view the judiciary as a major factor in campaign strategies so long as races are close. As a result, litigation rates should remain at a higher level than they were in 2000 whenever the race is close. As the closeness of

15 See, for example, Bay County Democratic Party v. Land, 347 F. Supp. 2d 404 (E.D.Mich. 2004). That case challenged ballot tabulation procedures in Michigan and relied explicitly on Bush v. Gore. 
the race diminishes, the rate of litigation should also decrease, although we doubt it will return to the levels of 1992 and 1996 in the foreseeable future. It should be noted that this trend is not limited to just presidential elections. The litigation surrounding both the recall election in California in 2003 and the San Diego mayoral and Washington gubernatorial races in 2004 fit the same trend.

This judicialization of elections has profound implications at both the state and federal level. First, if federal courts continue to remain as active in election litigation as they were in 2004, the stakes for the parties over federal judicial appointments could increase. As the importance of the judiciary in resolving disputes over electoral rules and procedures increases, the incentives for politicians to appoint loyal partisans to the bench will also increase. Such a development would likely lead to even greater political conflict in judicial confirmations, since the results could have a direct effect on the races of members of Congress and presidents. Thus, as elections become judicialized, the judiciary becomes increasingly politicized. At the state level, where the judiciary is primarily filled through gubernatorial appointments and elections, the results would likely mirror the contentiousness of the federal level, with increased rancor in elections and consideration of partisan loyalties by appointing bodies.

Our research also implies a shift in responsibility away from electoral boards and secretaries of state and to the judiciary. There are at least two potential positive outcomes from this shift. The first is that the courts could act less as partisans and more as "responsible" keepers of the law. The potential for partisan abuses of authority by electoral boards and secretaries of state abounds. Certainly in Florida, there were many accusations of partisanship against Republican Secretary of State Glenda Hood for her intent to use the felony purge list despite its many shortcomings. Courts, assuming they are more removed from electoral pressures, may serve as a more stable and reliable institution for resolving contentious political disputes. Secondly, as Tokaji argues, litigation offers the opportunity to clarify confusing election legislation and regulations prior to their implementation (Tokaji 2005, 1243-1244).
It is better to resolve these disputes prior to election day than to have extensive post-election battles, with the important caveat that the cases be filed far enough in advance to actually solve any identified problems in time. These potential benefits may be mitigated, however, by an increase in the politicization of the judiciary as discussed above. There also is some reason for concern to the extent the running of elections is taken away from those most knowledgeable about them and given instead to generalist judges. Finally, these developments suggest that the role of the parties in elections will continue to increase as they coordinate the litigation efforts and resources across the electoral college landscape.

We can conclude that future closely contested states should show similar litigation emerging throughout the year before any close election. This development is consistent with the literature on the conditions necessary for the judicialization of elections. Additional research that illuminates the source of the funds for litigation, the degree of coordination across venues, and the expected overlap of the legal elites across litigation forums may solidify our conception of the scope and importance of the judicialization of presidential elections.

\section{REFERENCES}

Ansolabehere, Stephen and Alan Gerber. 1996. "The Effects of Filing Fees and Petition Requirements on U.S. House Elections," Legislative Studies Quarterly 21: 249-264.

Balkin, Jack. 2001. "Bush v. Gore and the Boundary Between Law and Politics," 110 Yale Law Journal 110: 1407-1458.

Banks, Christopher P., David B. Cohen, and John C. Green. 2005. The Final Arbiter:The Consequences of Bush v. Gore for Law and Politics (New York: SUNY Press).

Burden, Barry C. 2005. "Ralph Nader's Campaign Strategy in the 2000 U.S. Presidential Election," American Politics Research 33: 672-99.

-2006. "Minor Parties and Strategic Voting in Recent U.S. Presidential Elections," Electoral Studies 24:603-18.

Chemerinsky, Erwin. 2001. “Bush v. Gore Was Not Justiciable," Notre Dame Law Review 76: 1093-112.

Clayton, Cornell. 2002. "The Supply and Demand Sides of Judicial Policymaking (Or, Why Be So Positive About the Judicialization of Politics?)," Law \& Contemporary Problems 65: 69-85. 
Cook Political Report. 2004. "Cook Electoral Ratings" <http://www.cnn.com/ELECTION/2004/special/ president/showdown/cook.html> (last accessed June 13, 2006).

Federal Electoral Commission. 2004. "Federal Election Commission Advisory Opinion Number 2004-35," <http://ao.nictusa.com/ao/no/040035.html> (last accessed June 13, 2006).

Ferejohn, John. 2002. "Judicializing Politics, Politicizing Law," Law \& Contemporary Problems 65: 41.

Florida Department of State (Division of Elections). 2000. "Official Florida Presidential Election Results," $<$ http://election.dos.state.fl.us/elections/resultsarchive/Index.asp > (last accessed June 13, 2006).

Florida Department of State (Division of Elections). 2004. "Official Florida Presidential Election Results," <http://election.dos.state.fl.us/elections/resultsarchive/Index.asp > (last accessed June 13, 2006).

Foley, Edward N. Forthcoming 2007. "The Future of Bush v. Gore," Ohio State Law Journal 68:

Garrett, Elizabeth. 2001. "Leaving the Decision to Congress," in The Vote: Bush, Gore, and the Supreme Court, Cass Sunstein and Richard Epstein, eds. (Chicago: University of Chicago Press): 38-54.

Gibson, James L., Gregory A. Caldeira, and Lester Kenyatta Spence. 2003. "The Supreme Court and the US Presidential Election of 2000: Wounds, Self-Inflicted or Otherwise?" British Journal of Political Science 33: 535-556.

Gillman, Howard. 2001. The Votes That Counted: How The Supreme Court Decided The 2000 Presidential Election (Chicago: University of Chicago Press).

Hasen, Richard L. 2001. "Bush v. Gore and the Future of Equal Protection Law in Elections," Florida State University Law Review 29: 377-406.

_2004. " A Critical Guide to Bush v. Gore Scholarship," Annual Review of Political Science 7: 297-313.

- 2005. "Beyond the Margin of Litigation: Reforming U.S. Election Administration to Avoid Electoral Meltdown," Washington and Lee Law Review 6: 937-999.

Hirschl, Ran. 2002. "Resituating the Judicialization of Politics: Bush v. Gore as a Global Trend," Canadian Journal of Law and Jurisprudence 15: 191-218.

- 2004. Towards Juristocracy: The Origins and Consequences of the New Constitutionalism (Cambridge, MA: Harvard University Press).

Jacobson, Gary C. 2003. "Partisan Polarization in Presidential Support: The Electoral Connection," Congress $\mathcal{E}$ The Presidency 30: 1-36.

Levinson, Sanford. 2002. "Bush v. Gore and the French Revolution: A Tentative List of Some Early Lessons," Law \& Contemporary Problems 65: 7-39.

Lewis-Beck, Michael S. and Peverill Squire. 1995. "The Politics of Institutional Choice: Presidential Ballot Ac- cess for Third Parties in the United States," British Journal of Political Science 25: 419-427.

Lowenstein, Daniel H. Forthcoming 2007. “The Meaning of Bush v. Gore," Ohio State Law Journal 68:

Mebane, Walter R. Jr. 2004. "The Wrong Man is President: Overvotes in the 2000 Presidential Election in Florida," Perspectives on Politics 2: 525-535.

Nagourney, Adam and Kathryn Seelye. 2004. "The 2004 Campaign: Strategy, Bush and Kerry Focus On 11 Key States," New York Times, sec. 1 p. 1, October 24.

Pildes, Richard H. 2004. "The Constitutionalization of Democratic Politics," Harvard Law Review 118: 28-154.

Posner, Richard A. 2001. Breaking the Deadlock: The 2000 Election, the Constitution, and the Courts (New York: Princeton University Press).

Shapiro, Martin and Alec Stone Sweet. 2002. On Law, Politics, and Judicialization (New York: Oxford University Press).

Stone, Andrea. 2004. "Despite Charges of Being 'Spoiler', Nader Unapologetic For Campaign," USA Today, sec. A p. 15, November 3.

Sunstein, Cass R. and Richard A. Epstein, eds. 2001. The Vote: Bush, Gore, and the Supreme Court (Chicago: University of Chicago Press).

Tate, C. Neal and Torbjorn Vallinder, eds. 1995. The Global Expansion of Judicial Power (New York: New York University Press).

Tokaji, Daniel P. 2005. "Early Returns on Election Reform: Discretion, Disenfranchisement, and the Help America Vote Act," George Washington Law Review 73: 1206-1254.

\section{CASES CITED}

Bush v. Palm Beach County Canvassing Board, 531 U.S. 70 (2000).

Bush v. Gore, 531 U.S. 98 (2000).

Bay County Democratic Party v. Land, 347 F. Supp. 2d 404 (E.D. Mich. 2004).

Summit County Democratic Central \& Executive Commiltee v. Blackwell, 388 F.3d 547 (6th Cir. 2004).

Address reprint requests to: Christopher Shortell

Department of Political Science

California State University, Northridge

Northridge, CA 91330-8254

E-mail: cshortell@csun.edu 
This article has been cited by:

1. Kyle C. Kopko. 2008. Partisanship Suppressed: Judicial Decision-Making in Ralph Nader's 2004 Ballot Access Litigation. Election Law Journal: Rules, Politics, and Policy 7:4, 301-324. [Citation] [Full Text PDF] [Full Text PDF with Links] 